\title{
МЕЖКУЛЬТУРНЫЕ ОТНОШЕНИЯ В РОССИЙСКОМ КРЫМУ: ЭМПИРИЧЕСКАЯ ПРОВЕРКА ТРЕХ ГИПОТЕЗ
}

\author{
Е.А. КОДЖА \\ 3.Х. ЛЕПШОКОВА ${ }^{\text {a }}$ Т.А. РЯБИЧЕНКО
}

${ }^{a}$ Национальньй исследовательский университет «Высшая икола экономики», 101000, Россия, Москва, ул. Мясницкая, д. 20

\section{Резюме}

В статье рассматриваются межкультурные отношения в Крыму - одном из поликультурных регионов России. Целью исследования являлась проверка трех гипотез межкультурных отношений: мультикультурализма, интеграции и контакта. Участниками исследования стали 195 русских, составляющих этническое большинство в Крыму, а также представители этнических меньшинств - 196 крымских татар и 196 украинцев. Для проверки гипотез использовался путевой анализ. Дополнительно были проведены 25 интервью с представителями трех этнических групп для более глубокого анализа результатов количественного исследования. Результаты исследования показали, что гипотеза мультикультурализма подтвердилась частично: у русских и украинцев воспринимаемая безопасность значимо позитивно связана с поддержкой мультикультурной идеологии и предпочтением интеграции, у крымских татар - только с поддержкой мультикультурной идеологии; взаимосвязи безопасности и толерантности в трех выборках не обнаружено. Гипотеза контакта также подтвердилась частично: у русских межкультурные дружеские контакты значимо позитивно связаны с их установками на толерантность, у украинцев - с предпочтением стратегии интеграции; у татар - и с установками на толерантность, и с предпочтением стратегии интеграции. Гипотеза интеграции подтвердилась полностью: предпочтение интеграции позитивно взаимосвязано с удовлетворенностью жизнью и самоуважением. Однако предпочтение сепарации также имеет значимую позитивную взаимосвязь с самоуважением у крымских татар и с удовлетворенностью жизнью у представителей всех трех групп. Полученные результаты рассматриваются через призму социокультурного и исторического контекста межэтнических отношений в Крыму.

Ключевые слова: межкультурные отношения, аккультурация, этническое меньшинство, мультикультурализм, интеграция, межкультурные контакты, Крым.

\section{Введение}

Сегодня межкультурные отношения в российском Крыму, который стал одним из самых поликультурных регионов России, вызывают интерес у всего

Исследование выполнено при поддержке гранта Российского научного фонда (проект № 15-18-00029). 
мирового сообщества, но комплексных социально-психологических исследований, дающих оценку складывающимся межкультурным отношениям и прогнозам их дальнейшего развития, недостаточно. В нашем исследовании впервые осуществлена проверка трех гипотез межкультурных отношений (мультикультурализма, контакта и интеграции) в российском Крыму.

\section{Межкультурные отношения в Крыму: социокультурный контекст}

Крым является одним из поликультурных регионов России. На территории Республики Крым и г. Севастополя русские занимают первое место по численности населения (около 68 \%), самое многочисленное этническое меньшинство составляют украинцы (около 16\%). Крымские татары являются коренным народом Крыма и составляют второе по численности этническое меньшинство - около 10\% (Федеральная служба государственной статистики, 2015). Численность крымскотатарского населения непрерывно увеличивалась с 1989 г. после реабилитации крымских татар и их массового возвращения в Крым (крымские татары, наряду с другими народами, подверглись в 1944 г. депортации в Центральную Азию, на Урал, в Сибирь). В результате референдума 16 марта 2014 г. Крым вошел в состав России, все жители Крыма стали гражданами Российской Федерации. Согласно новой Конституции Республики Крым, государственными языками в Крыму являются русский, украинский и крымскотатарский․․ Вопрос статуса русского языка стоял довольно остро, когда Крым был в составе Украины и когда украинский язык был единственным государственным языком, что способствовало постепенному вытеснению русского языка из официальной сферы. При этом русский язык оставался языком межнационального общения в Крыму, большинство населения (84,1\%) считает русский язык родным (Там же).

Крым также является поликонфессиональным регионом России. Бо́льшая часть населения исповедует православие (русские, украинцы, греки, болгары), есть некоторое число католиков, протестантов, иудеев. Около 15\% населения Крыма, в том числе крымские татары, исповедует ислам. Возрождение ислама в Крыму связано с репатриацией крымских татар. В настоящее время в Крыму, как и в исламском мире в целом, наблюдается усиление роли политического и радикального ислама, особенно среди молодежи. Межэтнические отношения в Крыму характеризуются определенной степенью напряженности, что обусловлено историческими, политическими и социально-экономическими вызовами последних десятилетий. В 1990-е гг. отношения обострились в связи с массовым возвращением крымских татар, которое сопровождалось самовольным захватом земель, что вызвало недовольство местного населения.

Вхождение Крыма в состав России в 2014 г. способствовало обострению существовавшей ранее напряженности между этническими группами Крыма,

\footnotetext{
${ }^{1}$ Конституция Республики Крым (принята Государственным Советом Республики Крым 11 апреля 2014 г.) (http://constitution.garant.ru/region/cons_krim/).
} 
которые по-разному восприняли это событие. Если русское население Крыма в целом всегда тяготело к России, то украинцы в основном не приняли смену власти и негативно отреагировали на присоединение Крыма, что частично объясняет последовавший отток украинского населения (Там же). Крымские татары, учитывая их проукраинские политические ориентации, также были склонны негативно относиться к присоединению и считать нежелательной интеграцию Крыма в политическое, экономическое, правовое, социальное пространство России (Гузенкова и др., 2016).

Кроме того, присоединение Крыма к России сопровождалось изменением статуса этнических групп: русские, ранее составлявшие этническое меньшинство в составе Украины, оказались в положении этнического большинства, украинцы стали этническим меньшинством, статус крымских татар как этнического меньшинства сохранился. Подобная политическая трансформация также сопровождалась масштабной трансформацией идентичностей. В частности, возникла необходимость конструирования новой гражданской идентичности у всех этнических групп в связи со сменой гражданства. Если у русского населения Крыма процесс формирования сильной и стабильной российской идентичности прошел довольно быстро, то у крымских татар исследователи отмечают слабую идентификацию с Россией (Мукомель, Хайкин, 2016).

Политические, правовые, экономические преобразования в Крыму в целом способствуют формированию национальной (российской) идентичности. Например, вхождение Крыма в состав России в 2014 г. принесло крымским татарам официальное признание крымскотатарского народа незаконно репрессированным с необходимостью реабилитацийㄹ, а также признание крымскотатарского языка в качестве одного из государственных языков Республики Крым. Сделаны шаги к урегулированию на законодательном уровне проблемы земельных самозахватов

Как показывают исследования, несмотря на различное отношение этнических групп к вхождению Крыма в состав России и связанный с этим рост напряженности, важное место в самосознании всех этнических групп Крыма занимает региональная (крымская) идентичность. Эта общая идентичность («мы крымчане») выступает как объединяющая представителей всех этнических групп (Там же).

Население Крыма представляет собой уникальную социокультурную общность и вызывает особый интерес для исследования межэтнических отношений, принимая во внимание масштабный характер социальной и политической трансформации, сопровождавшейся изменением статуса этнических групп и усилением напряженности. Все это обусловливает необходи-

\footnotetext{
${ }^{2}$ См.: Указ Президента Российской Федерации «О мерах по реабилитации репрессированного крымско-татарского народа, а также армян, болгар, греков, немцев Крыма и государственной поддержке их возрождения и развития» (с изменениями и дополнениями) от 21 апреля 2014 г. № 268 (http://base.garant.ru/70641266/).

${ }^{3}$ См.: Законопроект Республики Крым от 30 июля 2014 г. ( http://crimea.gov.ru/textdoc/ru/ 6/project/1695.pdf).
} 
мость комплексного изучения межэтнических отношений в Крыму путем проверки (тестирования) трех гипотез межкультурных отношений: мультикультурализма, контакта и интеграции на представителях трех основных этнических групп Крыма.

\section{Теоретические основы исследования: три гипотезы межкультурных отношений}

На протяжении полувека известный канадский ученый Д. Берри, автор теории аккультурации, принимал активное участие в разработке политики мультикультурализма в Канаде, он проводил многочисленные теоретические и эмпирические исследования канадской политики мультикультурализма с точки зрения психологии. В результате были выдвинуты три гипотезы межкультурных отношений: мультикультурализма, контакта и интеграции (Berry, 1984), которые были проверены во многих странах, включая Россию (Berry, 2017).

Гипотеза мультикультурализма состоит в том, что уверенность в своей идентичности ведет к принятию других и уменьшению уровня дискриминации. Данная гипотеза базируется на том, что в основе принятия людей с другой культурой лежит чувство безопасности - культурной, экономической, физической. Она может быть подвергнута эмпирической проверке, что и было осуществлено позже в многочисленных исследованиях. Так, исследование в Новой Зеландии показало, что воспринимаемая безопасность и мультикультурная идеология позитивно взаимосвязаны, а низкий уровень межгрупповой угрозы ведет к позитивным установкам по отношению к мигрантам (Ward, Masgoret, 2008). В Латвии у латышей выявлены позитивные связи безопасности с толерантностью и мультикультурной идеологией (Лебедева, Татарко, 2017). Гипотеза мультикультурализма была эмпирически подтверждена и в России. Были обнаружены позитивные связи безопасности и этнической толерантности мигрантов с Кавказа и русских москвичей (Lebedeva, Tatarko, 2013), позитивные связи безопасности с мультикультурной идеологией и интеграцией мигрантов с Кавказа и Центральной Азии и русских в Центральной России (Рябиченко, Лебедева, 2017). Проведенные на Северном Кавказе исследования показали, что в Северной Осетии - Алании безопасность связана с толерантностью, мультикультурной идеологией и взаимной интеграцией осетин и русских (Галяпина, 2017), в Кабардино-Балкарии безопасность связана с мультикультурной идеологией балкарцев и русских, а воспринимаемая кабардинцами угроза негативно связана с толерантностью, мультикультурной идеологией и интеграцией русских (Лепшокова, 2017). В Дагестане выявлены связи между безопасностью, мультикультурной идеологией и интеграцией русских и аварцев (Галяпина, Лепшокова, 2017).

Гипотеза контакта состоит в том, что межкультурные контакты способствуют взаимному принятию при соблюдении определенных условий (равенство контактирующих индивидов или групп; добровольность контакта; поддержка межкультурных контактов со стороны политики, социальных 
норм и законов, запрещающих дискриминацию, и др.). Данная гипотеза была многократно проверена и доказала свою высокую валидность (Тropp, Pettigrew, 2005). Например, в исследовании межкультурных отношений в Испании установлено, что межкультурные социальные контакты иммигрантов связаны с высоким уровнем их культурной адаптации (Grad, 2017). Гипотеза контакта проверялась и в России, например, исследование взаимной аккультурации мигрантов и принимающего населения в Центральной России показало, что межкультурные контакты мигрантов из Средней Азии связаны с высоким уровнем этнической толерантности, тогда как межкультурные контакты представителей принимающего населения связаны с предпочтением интеграции мигрантов (Рябиченко, Лебедева, 2017). Исследования в республиках Северного Кавказа показали, что в Северной Осетии-Алании межкультурные дружеские контакты обусловлены предпочтением интеграции в межкультурном взаимодействии (Галяпина, 2017), в Кабардино-Балкарии ориентацией на интеграцию русских в республике (Лепшокова, 2017), в Дагестане - предпочтением стратегии интеграции (Галяпина, Лепшокова, 2017).

Гипотеза интеграции состоит в том, что двойная вовлеченность групп и их членов в поддержку своих самобытных культур и в жизнь общества в целом способствует достижению большего психологического и социального благополучия, чем участие в жизни только одной культурной группы. Данная гипотеза была подтверждена на разных выборках во многих странах. Эмпирические исследования и метаанализ показали, что стратегия интеграции связана с наиболее позитивными психологическими, социальными и межкультурными последствиями (Berry, 1997; Nguyen, Benet-Martinez, 2013). Эту связь подтверждают изучение мнений молодых иммигрантов в Европе (Abu-Rayya, Sam, 2017; Berry et al., 2006), недавние опросы иммигрантов в Канаде (Berry, Hou, 2016), российские работы по изучению проблем интеграции в Центральной России и на Северном Кавказе (Лебедева, 2017; Lebedeva, Tatarko, 2013) и исследование, проведенное в 17 странах (Berry, 2017). Учитывая социокультурный контекст Крыма, мы адаптировали данные гипотезы к нашему исследованию.

\section{Н1. Гипотеза мультикультурализма}

Чем выше уровень воспринимаемой безопасности, тем выше уровень поддержки мультикультурной идеологии, этнической толерантности и предпочтения интеграции у русских, украинцев и крымских татар.

\section{Н2. Гипотеза контакта}

Чем больше межкультурных дружеских контактов, тем выше уровень этнической толерантности и предпочтения интеграции у русских, украинцев и крымских татар.

\section{Н3. Гипотеза интеграции}

Чем выше предпочтение интеграции, тем выше уровень удовлетворенности жизнью и самоуважения у русских, украинцев и крымских татар.

Кроме выдвинутых гипотез, мы предположили, что в Крыму, который является одним из самых полиэтничных, полилингвистичных и поликонфес- 
сиональных регионов со сложным этническим составом населения и историей межэтнических отношений, значимую роль может играть стратегия сепарации в межкультурных отношениях. Как показывает анализ исследований (JasinskajaLahti et al., 2011; Kus-Harbord, Ward, 2015), выбор стратегии сепарации может предсказывать как позитивный результат аккультурации, так и негативный. Так, исследование межкультурных отношений в Республике Дагестан показало, что у аварцев стратегия сепарации позитивно связана с удовлетворенностью жизнью (Галяпина, Лепшокова, 2017). Исходя из вышесказанного, мы выдвигаем исследовательский вопрос: как связано предпочтение сепарации/ сегрегации с удовлетворенностью жизнью и самоуважением у русских, украинцев и крымских татар?

Теоретическая модель исследования представлена на рисунке 1.

\section{Метод}

\section{Выборка исследования}

Данное исследование проводилось в Республике Крым в 2018 г. Выборка включала представителей трех этнических групп: русские - этническое большинство, $\mathrm{N}=195$; татары - этническое меньшинство, $\mathrm{N}=197$; украинцы этническое меньшинство, $\mathrm{N}=196$. Общее количество респондентов $\mathrm{N}=588$. В таблице 1 представлены основные характеристики выборки.

\section{Методы исследования}

В данном исследовании были использованы шкалы из опросника MIRIPS (Mutual Intercultural Relations In Plural Societies), которые были переведены на русский язык и адаптированы на российской выборке (Лебедева, Татарко, 2009).

Рисунок 1

\section{Теоретическая модель}

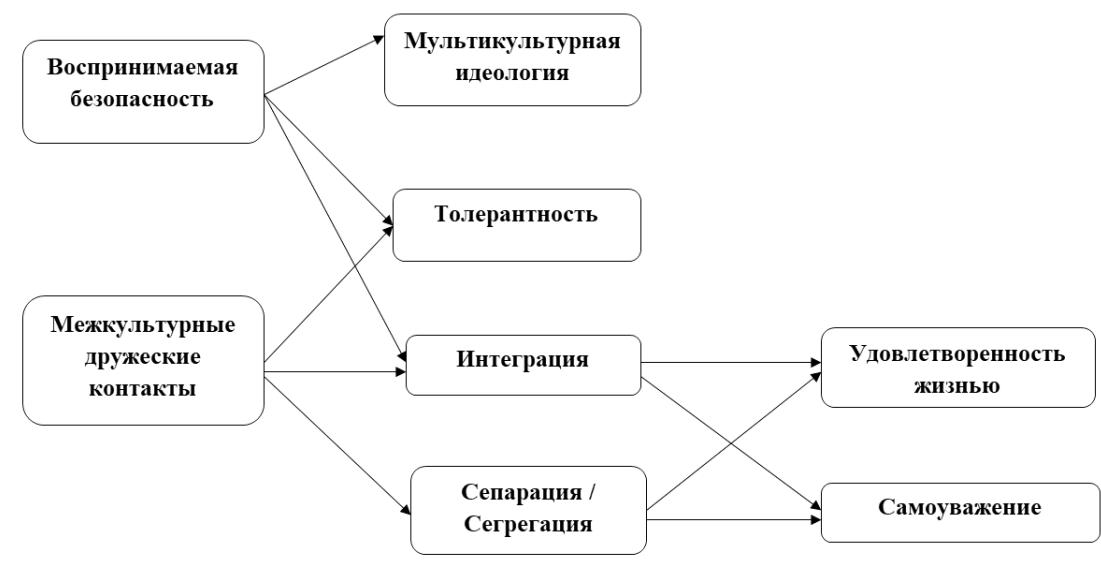


Воспринимаемая безопасность. Шкала включала 3 вопроса, например: «Крым - достаточно преуспевающая и богатая республика для того, чтобы каждый чувствовал себя в безопасности», $\alpha$ Кронбаха $=0.68_{\text {русские }} ; 0.71_{\text {украинцы }}$; 0.60

Межкультурные дружеские контакты. Данная шкала включала 2 вопроса: «Сколько у вас близких друзей русских/украинцев/крымских татар/представителей другой национальности?» и «Как часто вы встречаетесь с близкими друзьями русскими/украинцами/крымскими татарами/представителями других национальностей», $\alpha$ Кронбаха $=0.75_{\text {русские; }} ; 0.80_{\text {украинцы }} ; 0.79_{\text {крымские татары }}$

Мультикультурная идеология. Шкала включала 4 вопроса, например: «Общество, в котором существуют разнообразные этнические и культурные группы, более способно к решению новых, постоянно возникающих проблем», $\alpha$ Кронбаха $=0.69_{\text {русские }} ; 0.69_{\text {украинцы }} ; 0.57_{\text {крымские татары. }}$

Этническая толерантность. Шкала состояла из 3 вопросов, например: «Представители этнических меньшинств имеют такое же право выбирать будущее Крыма, как и русские», $\alpha$ Кронбаха $=0.66_{\text {русские }} ; 0.74_{\text {украинцы }} ; 0.57_{\text {крымские татары. }}$

Шкала Аккультурачионные предпочтения: Интеграчия включала 3 вопроса, например: для русских - «Я считаю, что этнические меньшинства, живущие в Крыму, должны как сохранять свои культурные традиции, так и осваивать русские»; для украинцев и крымских татар - «Я считаю, что украинцы/крымские татары, живущие в Крыму, должны как поддерживать собственные культурные традиции, так и усваивать русские», $\alpha$ Кронбаха = $=0.71_{\text {русские }} ; 0.63_{\text {украинцы }} ; 0.67_{\text {крымские татары }} ;$ Сепаращия включала 4 вопроса, например: для русских - «я считаю, что этнические меньшинства, живущие в Крыму, должны сохранять свои культурные традиции и не перенимать русские»; для украинцев и крымских татар - «Я предпочитаю участвовать в таких мероприятиях, в которые включены только украинцы/крымские татары», $\alpha$ Кронбаха $=0.54_{\text {русские }} ; 0.74_{\text {украинцы }} ; 0.75_{\text {крымские татары }}$.

Самоуважение. Была использована шкала Розенберга (Rosenberg, 1965), она включала 4 вопроса, например: «Я могу многое делать так же хорошо, как и большинство других людей», $\alpha$ Кронбаха $=0.80_{\text {русские }} ; 0.76_{\text {украинцы }} ; 0.79_{\text {крымские татары. }}$

Удовлетворенность жизнью. Шкала включала 4 вопроса, например: «У меня есть все, что мне необходимо в жизни» (все $\alpha \geqslant .82)$ (Diener et al., 1985), $\alpha$ Кронбаха $=0.86_{\text {русские }} ; 0.85_{\text {украинцы }} ; 0.86_{\text {крымские татары॰ }}$

Таблица 1

Гендерные и возрастные характеристики выборки

\begin{tabular}{|l|c|c|c|c|c|c|c|}
\hline \multirow{2}{*}{\multicolumn{1}{|c|}{ Респонденты }} & \multirow{2}{*}{$\mathbf{N}$} & \multicolumn{2}{c|}{ Пол } & \multicolumn{4}{c|}{ Возраст } \\
\cline { 3 - 8 } & & Мужчины & Женщины & Min. & Max. & M & SD \\
\hline Русские & 195 & $90(46 \%)$ & $105(54 \%)$ & 17 & 67 & 37.10 & 15.01 \\
\hline Украинцы & 196 & $96(49 \%)$ & $100(51 \%)$ & 17 & 67 & 36.01 & 13.99 \\
\hline Крымские татары & 197 & $98(49.7 \%)$ & $99(50.3 \%)$ & 17 & 66 & 36.67 & 14.53 \\
\hline
\end{tabular}


Сочиально-демографические характеристики. Мы исследовали также пол, возраст, образование и этническую принадлежность респондентов.

Математико-статистическая обработка данных. Для обработки данных использовался статистический пакет SPSS 22.0 с приложением AMOS 22.0. Применялись следующие методы: для измерения различий использовался многомерный дисперсионный анализ (MANOVA), для оценки надежности и согласованности шкал использовался показатель надежности коэффициент $\alpha$ Кронбаха, для проверки гипотез исследования использовался путевой анализ.

Первичный анализ данных потребовал проведения качественного исследования, позволяющего дополнить и глубже проанализировать результаты количественного исследования. Нами были проведены интервью с 25 респондентами, представителями трех этнических групп в возрасте от 18 до 70 лет, проживающих в Крыму. Использовалось полуструктурированное интервью, вопросы касались сохранения собственной культуры (языка, традиций, обычаев и пр.); были ориентированы на анализ особенностей межкультурного общения в семье, с соседями, на работе, в населенном пункте, в республике в целом; причин позитивных/негативных межкультурных отношений; психологического благополучия жителей Крыма и факторов, его определяющих; на определение перспектив развития межкультурных отношений в республике.

\section{Прочедура исследования}

Опрос был проведен среди жителей городов и сел, где компактно проживают представители исследуемых этнических групп, а также в Симферополе и Севастополе. Сбор количественных данных был проведен совместно с факультетом психологии Таврической академии Крымского федерального университета им. В.И. Вернадского (г. Симферополь) под руководством профессора Е.В. Черного. Интервью с жителями Крыма проводилось магистрами НИУ ВШЭ и сотрудниками Международной научно-учебной лаборатории социокультурных исследований НИУ ВШЭ.

\section{Результаты исследования межкультурных отношений в Республике Крым}

Проведенный анализ сравнения средних значений исследуемых переменных у представителей трех этнических групп с помощью MANOVA, где этническая принадлежность являлась независимой переменной, а воспринимаемая безопасность, межкультурные дружеские контакты, мультикультурная идеология, толерантность, интеграция, сепарация, удовлетворенность жизнью и самоуважение - зависимыми переменными, показал, что существуют значимые различия между русскими, украинцами и крымскими татарами: Wilks's $\lambda=0.738, F(16,1158)=11.877, p=0.000, \eta^{2}=0.141$. Значимые различия выявлены в выраженности воспринимаемой безопасности, в межкультурных дружеских контактах, мультикультурной идеологии, интеграции 
Таблица 2

Сравнение средних значений основных переменных исследования у русских, украинцев и крымских татар

\begin{tabular}{|c|c|c|c|c|c|}
\hline & Русские & Украинцы & Татары & \multirow{2}{*}{$F(2,584)$} & \multirow{2}{*}{ Partial $\eta^{2}$} \\
\hline & $\mathrm{M}(\mathrm{SD})$ & $\mathrm{M}(\mathrm{SD})$ & $\mathrm{M}(\mathrm{SD})$ & & \\
\hline $\begin{array}{l}\text { Воспринимаемая } \\
\text { безопасность }\end{array}$ & $3.88(0.82)_{a}$ & $3.67(0.86)_{\mathrm{b}}$ & $3.50(0.72)_{\mathrm{b}}$ & 10.855 & $0.036^{* * *}$ \\
\hline $\begin{array}{l}\text { Межкультурные } \\
\text { дружеские контакты }\end{array}$ & $3.03(1.00)_{\mathrm{a}}$ & $3.26(1.00)_{\mathrm{ab}}$ & $3.38(1.01)_{\mathrm{b}}$ & 5.915 & $0.020 * *$ \\
\hline $\begin{array}{l}\text { Мультикультурная } \\
\text { идеология }\end{array}$ & $3.91(0.65)_{\mathrm{a}}$ & $3.99(0.72)_{\mathrm{a}}$ & $4.17(0.55)_{\mathrm{b}}$ & 8.449 & $0.028 * * *$ \\
\hline Толерантность & $3.57(1.01)_{\mathrm{a}}$ & $3.56(1.00)_{\mathrm{a}}$ & $3.39(1.00)_{\mathrm{a}}$ & 1.953 & 0.007 \\
\hline Интеграция & $3.97(0.65)_{\mathrm{a}}$ & $3.89(0.72)_{\mathrm{ab}}$ & $3.77(0.73)_{\mathrm{b}}$ & 4.110 & $0.014^{*}$ \\
\hline $\begin{array}{l}\text { Сепарация/Сегрегация } \\
\text { у русских }\end{array}$ & $2.51(0.67)_{\mathrm{a}}$ & $2.32(0.83)_{\mathrm{a}}$ & $3.11(0.93)_{\mathrm{b}}$ & 50.202 & $0.146^{* * *}$ \\
\hline Самоуважение & $4.30(0.56)_{a}$ & $4.25(0.56)_{\mathrm{a}}$ & $4.31(0.55)_{\mathrm{a}}$ & .600 & 0.002 \\
\hline $\begin{array}{l}\text { Удовлетворенность } \\
\text { жизнью }\end{array}$ & $3.34(0.92)_{a}$ & $3.27(0.93)_{a}$ & $3.46(0.89)_{\mathrm{a}}$ & 2.083 & 0.007 \\
\hline
\end{tabular}

Примечание. Индексами a, b, обозначены результаты попарных сравнений изучаемых групп (тест Тьюки). Совпадение индексов в строках означает отсутствие различий. Различающиеся индексы указывают на значимые различия $(p<0.05)$.

и сепарации. В таблице 2 представлены сравнения средних значений основных переменных исследования у русских, украинцев и крымских татар.

На рисунке 2 представлены результаты проверки трех гипотез на выборках русских, украинцев и крымских татар с использованием моделирования структурными уравнениями (путевой анализ).

Результаты исследования показали, что гипотеза мультикультурализма частично подтвердилась на всех выборках: у русских и украинцев воспринимаемая безопасность значимо позитивно связана с поддержкой мультикультурной идеологии и предпочтением интеграции, но не связана с толерантностью; у татар воспринимаемая безопасность имеет значимую позитивную взаимосвязь только с поддержкой мультикультурной идеологии. Кроме того, у русских и татар обнаружена значимая позитивная корреляционная связь воспринимаемой безопасности с межкультурными дружескими контактами.

Гипотеза контакта частично подтвердилась на выборках русских и украинцев и полностью - на выборке татар: у русских межкультурные дружеские контакты значимо позитивно связаны только с их установками на толерантность, у украинцев - только с предпочтением стратегии интеграции; у татар межкультурные дружеские контакты значимо позитивно связаны и с установ- 
Рисунок 2

Путевая модель проверки трех гипотез межкультурных отношений на выборке русских, украинцев и татар Крыма

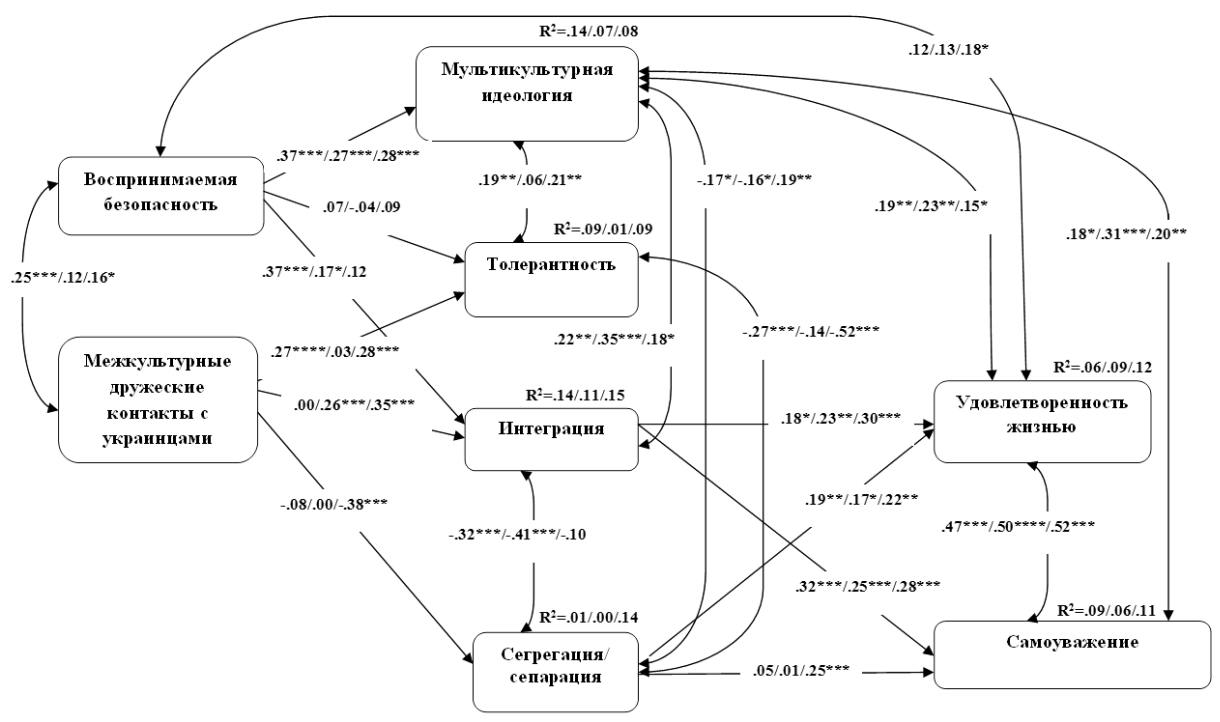

${ }^{*} p<0.05,{ }^{* *} p<0.01,{ }^{* * *} p<0.001$.

Примечание. Результаты трех групп представлены через слеш: русские/украинцы/татары. Параметры моделей удовлетворительны:

- русские $-\chi^{2} / \mathrm{df}=1.41 ; \mathrm{CFI}=0.986 ;$ RMSEA $=0.046 ;$ PCLOSE $=0.483 ; \mathrm{SRMR}=0.041$;

- украинцы $-\chi^{2} / \mathrm{df}=1.3 ; \mathrm{CFI}=0.98 ; \mathrm{RMSEA}=0.043$; PCLOSE $=0.507 ; \mathrm{SRMR}=0.041$;

- татары $-\chi^{2} / \mathrm{df}=1.17 ; \mathrm{CFI}=0.99 ; \mathrm{RMSEA}=0.03 ; \mathrm{PCLOSE}=0.643 ; \mathrm{SRMR}=0.046$

ками на толерантность, и с предпочтением стратегии интеграции. Кроме этого, у татар межкультурные дружеские контакты значимо отрицательно взаимосвязаны с предпочтением стратегии сепарации.

Гипотеза интеграции была полностью подтверждена на всех выборках: предпочтение интеграции значимо позитивно взаимосвязано как с удовлетворенностью жизнью, так и с самоуважением респондентов.

Было выявлено, что предпочтение сепарации имеет значимую позитивную взаимосвязь с удовлетворенностью жизнью у представителей всех трех групп, но взаимосвязь с самоуважением определена только у крымских татар.

Помимо тестирования гипотез, были обнаружены значимые позитивные корреляционные связи мультикультурной идеологии с удовлетворенностью жизнью и самоуважением у представителей всех трех этнических групп. У крымских татар была обнаружена значимая позитивная взаимосвязь воспринимаемой безопасности с удовлетворенностью жизнью (у русских и украинцев данная связь проявляется на уровне тенденции). 
Выявлены значимые позитивные корреляции между поддержкой мультикультурной идеологии и предпочтением интеграции у представителей всех исследуемых групп. Также на всех выборках обнаружены отрицательные взаимосвязи между толерантностью и предпочтением сепарации (у русских и татар данная связь значимая, у украинцев - на уровне тенденции), между интеграцией и сепарацией (у русских и украинцев данная связь значимая, у татар - на уровне тенденции). Корреляционная взаимосвязь поддержки мультикультурной идеологии и предпочтения сепарации у русских и украинцев является значимой отрицательной, а у татар - значимой положительной.

\section{Обсуждение}

Цель настоящего исследования состояла в проверке трех гипотез межкультурных отношений Д. Берри в группах русских, украинцев и крымских татарах, проживающих в Крыму.

Сравнение основных переменных исследования продемонстрировало достаточно благоприятный фон межкультурных отношений в Крыму. У представителей всех этнических групп нет различий в уровне психологического благополучия (удовлетворенности жизнью и самоуважения), они достаточно высоки. Уровень воспринимаемой безопасности и предпочтение интеграции меньшинств на полуострове значимо выше у этнического большинства (русских). У крымских татар (этнического меньшинства) поддержка мулитикультурной идеологии значимо выше, чем у русских и украинцев, а межкультурные дружеские контакты отличаются большей интенсивностью, чем у русских. При этом крымские татары предпочитают стратегию сепарации больше, чем русские и украинцы.

Далее с помощью путевого анализа мы оценили степень подтверждения гипотез настоящего исследования. Гипотеза мультикультурализма подтвердилась частично во всех исследуемых этнических группах, однако со своими особенностями. У русских и украинцев безопасность позитивно взаимосвязана с мультикультурной идеологией и предпочтением интеграции, у крымских татар только с мультикультурной идеологией, при этом ни в одной группе воспринимаемая безопасность не связана с этнической толерантностью.

Это полностью согласуется с рядом предыдущих исследований, выявивших связь безопасности с мультикультурной угрозой и установками на интеграцию в Новой Зеландии (Ward, Masgoret, 2008), Эстонии (Kruusvall et al., 2009) и России (Галяпина, Лепшокова, 2017; Лепшокова, 2017; Рябиченко, Лебедева, 2017), но не согласуется с исследованиями, выявившими связь безопасности и этнической толерантности в России (Галяпина, 2017; Lebedeva, Tatarko, 2013) и Латвии (Лебедева, Татарко, 2017). По-видимому, для толерантности одной безопасности в Крыму недостаточно.

Гипотеза контакта подтвердилась полностью лишь на выборке крымских татар, межкультурные дружеские контакты которых способствуют их установкам на интеграцию и толерантность и препятствуют сепарации в межэтническом взаимодействии. Данная гипотеза подтвердилась частично у русских и 
украинцев, при этом у русских контакты связаны с толерантностью, тогда как у украинцев - со стратегией интеграции. В предыдущих исследованиях было показано, что межкультурные контакты мигрантов связаны с высоким уровнем этнической толерантности, тогда как межкультурные контакты представителей принимающего населения связаны с предпочтением интеграции мигрантов (Рябиченко, Лебедева, 2017). Исследования в республиках Северного Кавказа (РСО-А, КБР, Дагестан) показали, что межкультурные дружеские контакты связаны с предпочтением взаимной интеграции в межкультурном взаимодействии (Галяпина, 2017; Галяпина, Лепшокова, 2017; Лепшокова, 2017).

Гипотеза интеграции подтвердилась полностью на выборках всех исследуемых этнических групп: межкультурная интеграция способствует психологическому благополучию жителей Крыма независимо от их этнического происхождения. Это согласуется с многочисленными исследованиями на разных выборках во многих странах (Лебедева, 2017; Berry, 2017; Berry, Hou, 2016; Lebedeva, Tatarko, 2013; Nguyen, Benet-Martinez, 2013).

В нашем исследовании, исходя из ранее проведенных исследований и особенностей социокультурного контекста Крыма, мы выдвинули исследовательский вопрос: как связана установка на сепарацию/сегрегацию с удовлетворенностью жизнью и с самоуважением у русских, украинцев и крымских татар? Выяснилось, что у русских и украинцев стратегия сепарации сопряжена с удовлетворенностью жизнью, но не сочетается с самоуважением, тогда как у крымских татар стратегия сепарации оказалась связанной как с удовлетворенностью жизнью, так и с самоуважением.

Согласно предыдущим исследованиям, сепарация является предиктором хорошей психологической, но плохой социокультурной адаптации мигрантов (Berry et al., 2006). Несмотря на то что интеграция в целом сулит наибольшие выгоды при адаптации, другие способы аккультурации, в частности сепарация, могут быть полезны в некоторых случаях. Согласно последним исследованиям на репрезентативной выборке иммигрантов в Канаде, у тех, кто предпочитал сепарацию, был высокий уровень психического здоровья (Berry, Hou, 2016). В ассимиляционистском контексте Эстонии более высокие уровни психологического благополучия были присущи тем представителям этнических меньшинств, которые были нацелены на ассимиляцию или сепарацию (Kus-Harbord, Ward, 2015; Kruusvall et al., 2009).

Согласно модели отвержения-идентификации (Rejection-Identification Model; Branscombe et al., 1999), члены притесняемых групп ищут поддержки у своей группы в ситуации дискриминации, и их этническая идентичность становится более выраженной. Это дает им чувство принадлежности и смягчает психологические последствия воспринимаемой дискриминации, что может объяснить, почему в некоторых случаях сепарация может играть адаптивную роль (Sam, Berry, 2016).

Крым с его сложной историей и в свете последних событий смены государственной принадлежности - пример получения психологической поддержки представителями каждой этнической группы во внутригрупповых 
контактах и в своей групповой идентичности. Результаты нашего качественного исследования это подтверждают. Ниже мы приводим выдержки из интервью с представителями крымских татар, украинцев и русских: «...Нет, есть, конечно, другие нации, но у нас почему-то всегда все любят вот кучковаться именно сами. <..> А сейчас вот, живя здесь, в Крыму, почему-то все татары тянутся к татарам, русские к русским, украинцы к украинцам. У меня кореянок сколько подруг было, и русские, и украинцы, всех было много. А у моих детей, по-моему, нету, у них все друзья татары крымские. Ну, может быть, одиндва...» (крымская татарка 57 лет). «...Когда я очень нервничаю, где-то серьезная проблема, я про себя начинаю говорить на украинском, это как бы слегка помогает в какой-то момент психологически. Те, кто были украинцами, у них очень сильно, сильнее чем я себе представляла, вот эта идентичность...» (украинка, 26 лет).

Однако, по данным нашего исследования, межкультурные контакты у русских способствуют толерантности, у украинцев - интеграции, у татар - толерантности, интеграции и не способствуют сепарации. Интеграция и мультикультурная идеология повышают психологическое благополучие представителей всех групп. У русских и татар межкультурные контакты и безопасность позитивно взаимосвязаны. Это означает, что условием психологического благополучия всех жителей Крыма являются чувство безопасности языка, культуры и идентичности, равноправные межкультурные контакты и интеграция. Отличительным признаком Крыма является естественно сложившаяся поликультурность, которую местные жители воспринимают как данность и к которой относятся положительно. «...У меня управляющий компании казанский татарин, исполнительный директор - украинеи, а генеральный директор вообще из Турции... Ну и, соответственно, т.е. как был и коллектив у нас, непосредственно там, менеджер по закупкам и энергетик - это крымские татары, ландиафтный дизайнер - русская. И все мы вместе, и все мы ладим очень хорошо...» (украинка, 25 лет). «У нас здесь многоначиональный город. Здесь и армяне, и азербайджанць, и грузинь, и чеченцы, и дагестанщы, и башкирь и все кто хочешь есть... я не против, пожалуйста...» (крымский татарин, 27 лет). «...Крымчане отличаются тем, что тут уживается много народов, $и$ мы все живем в мире, особенно в Евпатории. Когда отстраивали церковь, мечеть, синагогу, если у одной религиозной общины возникали трудности другая ей помогала...» (крымский татарин, 42 года). «...Ну, наверно, да, многонациональный. Но он всегда таким был. Он не стал вчера таким, не стал с присоединением к России таким. Я тут живу с детства, и он такой с детства, я другого Крыма и не знаю по факту» (русская, 26 лет).

Особенность Крыма, которая предполагает объединение культур, также формирует у людей особое отношение к этому месту, идентификацию с ним. Многие участники опроса отмечали, что все они «крымчане», что для них очень важно быть частью Крыма, его истории, культуры. «...Я крымчанин, $я$ здесь родился, вырос, это мой дом...» (крымский татарин, 19 лет). «..Я все время говорю, что я крымчанка, я родилась в Крыму, я здесь выросла...» (русская, 19 лет). «...Живя там (в Ташкенте), все равно мы были гости. Я не могу 
назвать Узбекистан родиной, я там родилась, но родина все равно моя здесь, $а$ там мы просто родилисъ...» (крымская татарка, 57 лет).

Данные количественного и качественного социально-психологического исследования межкультурных отношений в Крыму позволяют нам сделать вывод о благоприятном фоне этих отношений и векторе развития Крыма в полноценное мультикультурное общество, заботящееся о сохранении культур всех населяющих его народов и стремящееся к интеграции на базе единой «крымской» идентичности, которая способствует их самоуважению и удовлетворенности жизнью.

\section{Литература}

Галяпина, В. Н. (2017). Межкультурные отношения в Республике Северная Осетия-Алания. В кн. Н. М. Лебедева (ред.), Межкультурные отношения на постсоветском пространстве (с. 186-211). М.: Менеджер.

Галяпина, В. Н., Лепшокова, 3. Х. (2017). Межэтнические отношения в современном Дагестане. В кн. Н. М. Лебедева (ред.), Межкультурные отношения на постсоветском пространстве (с. 212-239). М.: Менеджер.

Гузенкова, Т. С., Неменский, О. Б., Хизриева, Г. А. (2016). Крымские татары: Особенности и проблемы интеграции в российское пространство. Проблемы национальной стратегии, 4(37), 31-57.

Лебедева, Н. М. (һед.). (2017). Межкультурные отношения на постсоветском пространстве. М.: Менеджер.

Лебедева, Н. М., Татарко, А. Н. (ред.) (2009). Стратегии межкультурного взаимодействия мигрантов и принимающего населения России. М.: РУДН.

Лебедева, Н. М., Татарко, А. Н. (2017). Межкультурные отношения латышей и русских в постсоветской Латвии. В кн. Н. М. Лебедева (ред.), Межкультурные отношения на постсоветском пространстве (с. 301-323). М.: Менеджер.

Лепшокова, 3. Х. (2017). Межкультурные отношения кабардинцев, балкарцев и русских в Кабардино-Балкарской Республике. В кн. Н. М. Лебедева (ред.), Межкультурные отношения на постсоветском пространстве (с. 156-186). М.: Менеджер.

Мукомель, В. И., Хайкин, С. Р. (2016). Крымские татары после «крымской весны»: Трансформация идентичностей. Мониторинг общественного мнения: Экономические и сочиальные перемены, 3, 51-68.

Рябиченко, Т. А., Лебедева, Н. М. (2017). Взаимная аккультурация мигрантов и принимающего населения в центральной России. В кн. Н. М. Лебедева (ред.), Межкультурные отношения на постсоветском пространстве (с. 57-81). М.: Менеджер.

Федеральная служба государственной статистики. (2015). Итоги переписи населения в Крымском федеральном округе. М.: ИИЦ «Статистика России» (http://www.gks.ru/free_doc/ new_site/population/demo/perepis_krim/KRUM_2015.pdf).

Ссылки на зарубежные источники см. в разделе References после англоязычного блока. 
Коджа Екатерина Андреевна - аспирант, департамент психологии, факультет социальных наук; стажер-исследователь, Международная научно-учебная лаборатория социокультурных исследований, Экспертный институт, Национальный исследовательский университет «Высшая школа экономики».

Сфера научных интересов: межкультурные отношения, идентичность, кросс-культурная психология.

Контакты: ekodja@hse.ru

Лебедева Надежда Михайловна - заведующая, Международная научно-учебная лаборатория социокультурных исследований, Экспертный институт; профессор, департамент психологии, факультет социальных наук, Национальный исследовательский университет «Высшая школа экономики», доктор психологических наук, профессор.

Сфера научных интересов: этническая и кросс-культурная психология, межкультурные отношения, аккультурация мигрантов, трансмиссия ценностей, креативность, инновации. Контакты: nlebedeva@hse.ru

Галяпина Виктория Николаевна - ведущий научный сотрудник, Международная научноучебная лаборатория социокультурных исследований, Экспертный институт; доцент, департамент психологии, факультет социальных наук, Национальный исследовательский университет «Высшая школа экономики», кандидат психологических наук, доцент.

Сфера научных интересов: кросс-культурная психология, межкультурные отношения, ценности и нормы, идентичность.

Контакты: vgalyapina@hse.ru

Лепшокова Зарина Хизировна - старший научный сотрудник, Международная научноучебная лаборатория социокультурных исследований, Экспертный институт; доцент, департамент психологии, факультет социальных наук, Национальный исследовательский университет «Высшая школа экономики», кандидат психологических наук.

Сфера научных интересов: социальная и кросс-культурная психология, межкультурные отношения, аккультурация, ценности, множественные идентичности.

Контакты: zlepshokova@hse.ru

Рябиченко Татьяна Анатольевна - старший научный сотрудник, Международная научноучебная лаборатория социокультурных исследований, Экспертный институт; доцент, департамент психологии, факультет социальных наук, Национальный исследовательский университет «Высшая школа экономики», кандидат психологических наук.

Сфера научных интересов: межкультурные отношения, аккультурация, ценности, культурная преемственность, идентичность.

Контакты: tryabichenko@hse.ru 


\title{
Intercultural Relations in Russian Crimea: Empirical Testing of Three Hypotheses
}

\author{
E.A. Kodja ${ }^{\text {a }}$ N.M. Lebedeva ${ }^{a}$, V.N. Galyapina ${ }^{a}$, Z.Kh. Lepshokova ${ }^{a}$, T.A. Ryabichenko ${ }^{a}$ \\ ${ }^{a}$ National Research University Higher School of Economics, 20 Myasnitskaya Str., Moscow, 101000, \\ Russian Federation
}

\begin{abstract}
This article examines intercultural relations in Crimea - one of the multicultural regions of Russia. Our goal was to test three hypotheses in Crimea: the multiculturalism hypothesis, the integration hypothesis, and the contact hypothesis. The sample included members of the ethnic majority in Crimea, Russians $(\mathrm{N}=195)$, and members of the ethnic minorities, Crimean Tatars $(\mathrm{N}=197)$ and Ukrainians $(\mathrm{N}=196)$. Data processing was carried out using path analysis. We additionally conducted 25 interviews with the members of three ethnic groups to deeper analyze the results of the quantitative study. The results showed partial support for the multiculturalism hypothesis: perceived security was linked with support for a multicultural ideology and integration among Russians and Ukrainians, and support for multicultural ideology among Crimean Tatars, however, there was no significant correlation with tolerance in the three samples. The contact hypothesis was partially confirmed: intercultural contacts predicted support for tolerance among Russians, preference for integration among Ukrainians, and both tolerance and integration among Crimean Tatars. Integration hypothesis was fully confirmed: preference for integration promotes well-being in three samples. However, the preference for separation promoted self-esteem among Crimean Tatars and life satisfaction among three ethnic groups. The results of the research are discussed from the perspective of the socio-cultural and historical context of interethnic relations in Crimea.
\end{abstract}

Keywords: intercultural relations, acculturation, ethnic minority, multiculturalism, integration, intercultural contacts, Crimea.

\section{References}

Abu-Rayya, H. M., \& Sam, D. L. (2017). Is integration the best way to acculturate? A re-examination of the bicultural-adaptation relationship in the "ICSEY-data set" using the bilineal method. Journal of Cross-Cultural Psychology, 48(3), 287-293. doi:10.1177/0022022116685846

Berry, J. W. (1984). Multicultural policy in Canada: A social psychological analysis. Canadian Journal of Behavioural Science, 16, 353-370. doi:10.1037/h0080859

Berry, J. W. (1997). Immigration, acculturation, and adaptation. Applied Psychology, 46(1), 5-34. doi:10.1111/j.1464-0597.1997.tb01087.x

Berry, J. W. (Ed.). (2017). Mutual intercultural relations. Cambridge: Cambridge University Press. doi:10.1017/9781316875032

Berry, J. W., \& Hou, F. (2016). Acculturation and wellbeing among immigrants to Canada. Canadian Psychology: Special Issue on Immigrants and Refugees in Canada, 57, 254-264. doi:10.1037/cap0000064 
Berry, J. W., Phinney, J. S., Sam, D. L, \& Vedder, P. (2006). Immigrant youth: Acculturation, identity, and adaptation. Applied Psychology, 55, 303-332. doi:10.1111/j.1464-0597.2006.00256.x

Branscombe, N. R., Schmitt, M. T., \& Harvey, R. D. (1999). Perceiving pervasive discrimination among African-Americans: Implications for group identification and well-being. Journal of Personality and Social Psychology, 77, 135-149. doi:10.1037/0022-3514.77.1.135

Diener, E., Emmons, R. A., Larsen, R. J., \& Griffin, S. (1985). The Satisfaction with Life Scale.Journal of Personality Assessment, 49, 71-75. doi:10.1207/s15327752jpa4901_13

Federal State Statistics Service. (2015). Itogi perepisi naseleniya v Krymskom federal'nom okruge [Results of the population census in the Crimean Federal district]. Moscow: Statistika Rossii. Retrieved from http://www.gks.ru/free_doc/new_site/population/demo/perepis_krim/KRUM_2015.pdf (in Russian)

Galyapina, V. N. (2017). Mezhkul'turnye otnosheniya v Respublike Severnaya Osetiya-Alaniya [Intercultural relations in the Republic of North Ossetia-Alania]. In N. M. Lebedeva (Ed.), Mezhkul'turnye otnosheniya na postsovetskom prostranstve [Intercultural relations in the PostSoviet space] (pp. 186-211). Moscow: Menedzher. (in Russian)

Galyapina, V. N., \& Lepshokova, Z. H. (2017). Mezhetnicheskie otnosheniya v sovremennom Dagestane [Interethnic relations in contemporary Dagestan]. In N. M. Lebedeva (Ed.), Mezhkul'turnye otnosheniya na postsovetskom prostranstve [Intercultural relations in the PostSoviet space] (pp. 212-239). Moscow: Menedzher. (in Russian)

Grad, H. (2017). Intercultural relations in Spain. In J. W. Berry (Ed.), Mutual intercultural relations (pp. 249-267). Cambridge: Cambridge University Press. doi:10.1017/9781316875032.013

Guzenkova, T. S., Nemenskiy, O. B., \& Khizrieva, G. A. (2016). Krymskie tatary: Osobennosti i problemy integratsii v rossiyskoe prostranstvo [Crimean Tatars: specifics and problems of integration into the Russian space]. Problemy Natsional'noy Strategii [National Strategy Issues], 4(37), 31-57. (in Russian)

Jasinskaja-Lahti, I., Horenczyk, G., \& Kinunen, T. (2011). Time and context in the relationship between acculturation attitudes and adaptation among Russian-speaking immigrants in Finland and Israel. Journal of Ethnic and Migration Studies, 37(9), 1423-1440. doi:10.1080/1369183X.2011.623617

Kruusvall, J., Vetik, R., \& Berry, J. W. (2009). The strategies of inter-ethnic adaptation of Estonian Russians. Studies of Transition States and Societies, 1, 3-24.

Kus-Harbord, L., \& Ward, C. (2015). Ethnic Russians in post-Soviet Estonia: Perceived devaluation, acculturation, well-being, and ethnic attitudes. International Perspectives in Psychology: Research, Practice, Consultation, 4(1), 66-81. doi:10.1037/ipp0000025

Lebedeva, N. M. (Ed.). (2017). Mezhkul'turnye otnosheniya na postsovetskom prostranstve [Intercultural relations in the Post-Soviet space]. Moscow: Menedzher. (in Russian)

Lebedeva, N. M., \& Tatarko, A. N. (Eds.). (2009). Strategii mezhkul'turnogo vzaimodeystriya migrantov $i$ naseleniya Rossii: Sbornik nauchnykh statey [Strategies for the intercultural interaction of migrants and the population of Russia: A collection of scientific articles]. Moscow: RUDN University. (in Russian)

Lebedeva, N. M., \& Tatarko, A. N. (2013). Immigration and intercultural interaction strategies in postSoviet Russia. In E. Tartakovsky (Ed.), Immigration: Policies, challenges and impact (pp. 179-194). New York: Nova Science. 
Lebedeva, N. M., \& Tatarko, A. N. (2017). Mezhkul'turnye otnosheniya latyshej i russkih v postsovetskoj Latvii [Intercultural relations between Latvians and Russians in Post-Soviet Latvia]. In N. M. Lebedeva (Ed.), Mezhkul'turnye otnosheniya na postsovetskom prostranstve [Intercultural relations in the Post-Soviet space] (pp. 301-323). Moscow: Menedzher. (in Russian)

Lepshokova, Z. H. (2017). Mezhkul'turnye otnosheniya kabardintsev, balkartsev i russkih v Kabardino-Balkarskoy Respublike [Intercultural relations between Kabardians, Balkars and Russians in the Kabardino-Balkar Republic]. In N. M. Lebedeva (Ed.), Mezhkul'turnye otnosheniya na postsovetskom prostranstve [Intercultural relations in the Post-Soviet space] (pp. 156-186). Moscow: Menedzher. (in Russian)

Mukomel, V. I., \& Khaykin, S. R. (2016). Crimean Tatars after the "Crimean spring": transformation of identities. Monitoring Obshchestvennogo Mneniya: Economicheslie i Sotsial'nye Peremeny [Monitoring of Public Opinion: Economic and Social Changes Journal], 3, 51-68. (in Russian)

Nguyen, A.-M. D., \& Benet-Martinez, V. (2013). Biculturalism and adjustment: A meta-analysis. Journal of Cross-Cultural Psychology, 44, 122-159. doi:10.1177/0022022111435097

Rosenberg, M. (1965). Society and the adolescent self-image. Princeton, NJ: Princeton University Press. doi:10.1515/9781400876136

Ryabichenko, T. A., \& Lebedeva, N. M. (2017). Vzaimnaya akkul'turatsiya migrantov i prinimayshchego naseleniya $\mathrm{v}$ tsentral'noy Rossii [Mutual acculturation of migrants and the host population in Central Russia]. In N. M. Lebedeva (Ed.), Mezhkul'turnye otnosheniya na postsovetskom prostranstve [Intercultural relations in the Post-Soviet space] (pp. 57-81). Moscow: Menedzher. (in Russian)

Sam, D. L., \& Berry, J. W. (Eds.). (2016). Cambridge handbook of acculturation psychology (2nd ed.). Cambridge, UK: Cambridge University Press.

Tropp, L. R., \& Pettigrew, T. F. (2005). Relationships between intergroup contact and prejudice among minority and majority status groups. Psychological Science, 16, 951-957. doi:10.1111/j.14679280.2005.01643.x

Ward, C., \& Masgoret, A.-M. (2008). Attitudes toward immigrants, immigration and multiculturalism in New Zealand. International Migration Reviere, 42, 222-243. doi:10.1111/j.1747-7379.2007.00119.x

Ekaterina A. Kodja - research intern, International Scientific-Educational Laboratory for Socio-Cultural Research, Expert Institute; Ph.D. student, Faculty of Social Sciences, School of Psychology, National Research University Higher School of Economics.

Research area: intercultural relations, identity, cross-cultural psychology.

E-mail: ekodja@hse.ru

Nadezhda M. Lebedeva - head, International Laboratory for Socio-Cultural Research, Expert Institute; professor, Department of Psychology, Faculty of Social Sciences, National Research University "Higher School of Economics", D.Sc., professor.

Research area: ethnic and cross-cultural psychology, intercultural relations, acculturation of migrants, values transmission, creativity, innovation.

E-mail: nlebedeva@hse.ru

Victoria N. Galyapina - leading research fellow, International Scientific-Educational Laboratory for Socio-Cultural Research, Expert Institute; associate professor, Faculty of Social Sciences, School of Psychology, National Research University Higher School of Economics, Ph.D.

Research area: cross-cultural psychology, intercultural relations, values and norms, identity.

E-mail: vgalyapina@hse.ru 
Zarina Kh. Lepshokova - senior research fellow, International Scientific-Educational Laboratory for Socio-Cultural Research, Expert Institute; associate professor, Faculty of Social Sciences, School of Psychology, National Research University Higher School of Economics, Ph.D.

Research area: social and cross-cultural psychology, intercultural relations, acculturation, values, multiple identities.

E-mail: taimiris@yandex.ru; zlepshokova@hse.ru

Tatiana A. Ryabichenko - senior research fellow, International Scientific-Educational Laboratory for Socio-Cultural Research, Expert Institute; associate professor, Faculty of Social Sciences, School of Psychology, National Research University Higher School of Economics, Ph.D.

Research area: intercultural relations, acculturation, values, cultural continuity, identity. E-mail: tryabichenko@hse.ru 